\title{
A Fingerprint Matching Technique Based on Phase-Only Correlation
}

\section{- Algorithm Design and Implementation for Fingerprint Matching Devices Dedicated to Home Applications -}

\author{
Hiroshi Nakajima Member (Yamatake Corporation, nakajima-hiroshi-1@jp.yamatake.com) \\ Koji Kobayashi Non-member (Yamatake Corporation, koji-kobayashi@jp.yamatake.com) \\ Makoto Morikawa Non-member (Yamatake Corporation, morikawa-makoto@jp.yamatake.com) \\ Atsushi Katsumata Non-member (Yamatake Corporation, katsumata-atsushi@jp.yamatake.com) \\ Koichi Ito Non-member (Tohoku University, ito@aoki.ecei.tohoku.ac.jp) \\ Takafumi Aoki Non-member (Tohoku University, aoki@ecei.tohoku.ac.jp) \\ Tatsuo Higuchi Non-member (Tohoku Institute of Technology, higuchi@tohtech.ac.jp)
}

Keywords : Biometrics, Personal Authentication, Fingerprint Matching, Phase-Only Correlation

A major approach for fingerprint recognition today is to extract minutiae from fingerprint images and to perform fingerprint matching based on the number of corresponding minutiae pairings. One of the most difficult problems in minutiae-based fingerprint recognition has been that the recognition performance is significantly influenced by fingertip surface condition, which may vary depending on environmental or personal causes. Addressing this problem, we have proposed an efficient fingerprint recognition algorithm using phase-based image matching. The use of phase components in 2D discrete Fourier transforms of fingerprint images makes possible to achieve highly robust fingerprint recognition for low-quality fingerprints. However, due to its high computational complexity, the proposed algorithm is not suitable to be implemented in compact

Table 1. Performance comparison

\begin{tabular}{|c||c|c|c|}
\hline & MINUTIAE & BLPOC & PROPOSED \\
\hline \hline EER & 7.3 & 2.5 & 2.3 \\
\hline ZeroFMR & 17.4 & 5.0 & 4.3 \\
\hline
\end{tabular}

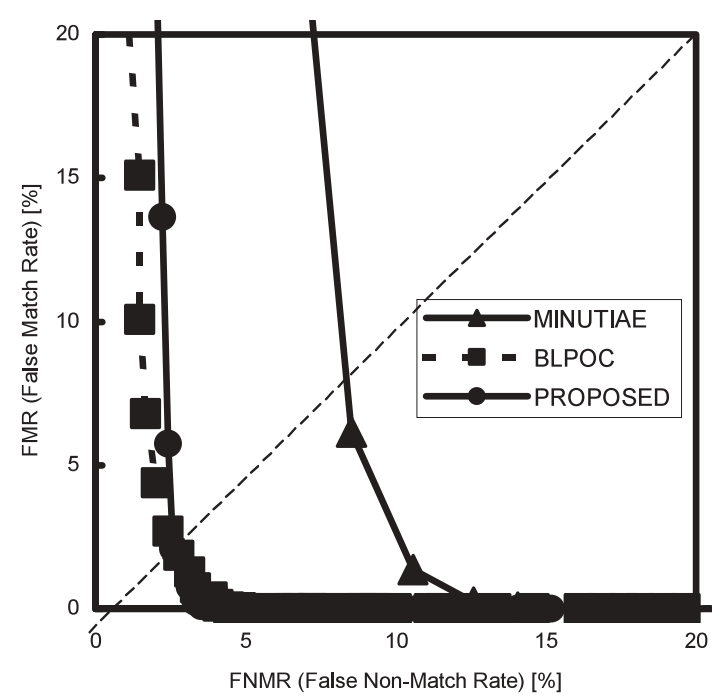

Fig. 1. Receiver operating characteristic curves fingerprint matching devices for home applications. In this paper, we propose an improved fingerprint recognition algorithm using phase-based image matching, which significantly reduces computational complexity without degrading recognition performance, compared with the reported algorithm (Table 1, Fig. 1). We also present prototype implementation of a high-performance, easy-to-use fingerprint matching device for home applications, which employ a specially designed ASIC for executing the proposed algorithm in real time (Fig. 2, Fig. 3)

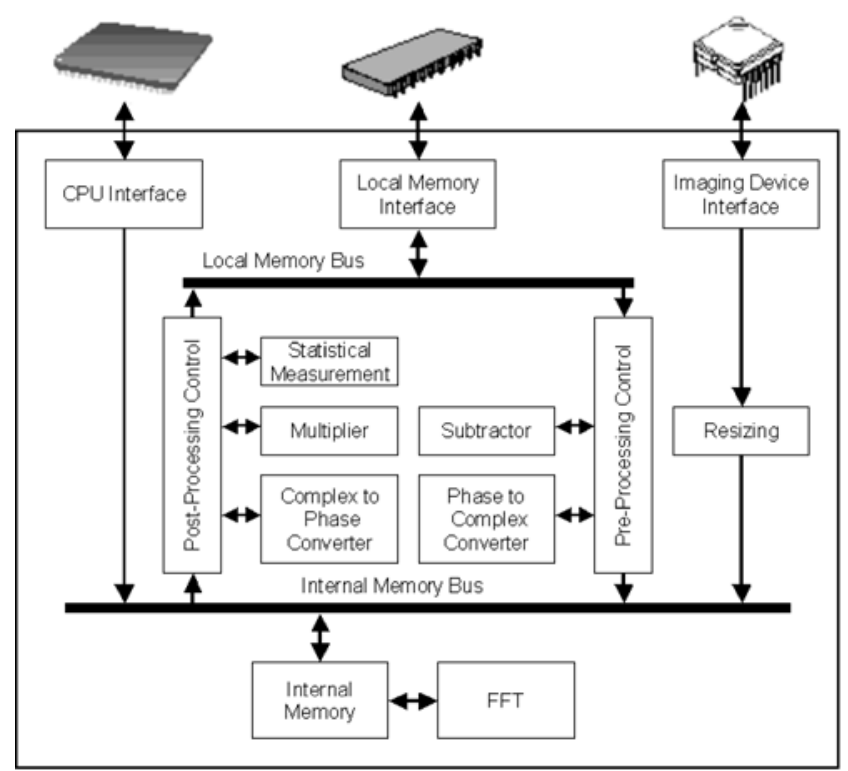

Fig. 2. Block diagram of ASIC

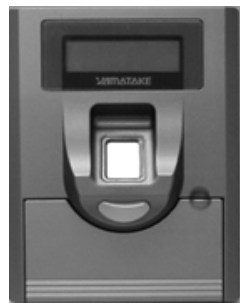

Fig. 3. Fingerprint recognition device 


\section{位相限定相関法に基づく指紋照合技術 \\ ———般住宅向け指紋照合装置のためのアルゴリズム設計と実現}

\begin{tabular}{|c|c|c|c|c|}
\hline 正 員 中島 & 寛 ${ }^{*}$ & 非会員 & 小林 & 孝次 ${ }^{*}$ \\
\hline 非会員 森川 & 誠 ${ }^{*}$ & 非会員 & 勝亦 & 敦 ${ }^{*}$ \\
\hline 伊藤 & 康一 ${ }^{* *}$ & 非会員 & 青木 & 孝文 $^{* *}$ \\
\hline 樋口 & 龍雄 $^{* * *}$ & & & \\
\hline
\end{tabular}

A Fingerprint Matching Technique Based on Phase-Only Correlation

- Algorithm Design and Implementation for Fingerprint Matching Devices Dedicated

to Home Applications -

Hiroshi Nakajima* ${ }^{*}$ Member, Koji Kobayashi* ${ }^{*}$ Non-member, Makoto Morikawa* ${ }^{*}$, Non-member,

Atsushi Katsumata ${ }^{*}$, Non-member, Koichi Ito ${ }^{* *}$, Non-member, Takafumi Aoki ${ }^{*}{ }^{*}$, Non-member,

Tatsuo Higuchi $^{* * *}$, Non-member

A major approach for fingerprint recognition today is to extract minutiae from fingerprint images and to perform fingerprint matching based on the number of corresponding minutiae pairings. One of the most difficult problems in minutiae-based fingerprint recognition has been that the recognition performance is significantly influenced by fingertip surface condition, which may vary depending on environmental or personal causes. Addressing this problem, we have proposed an efficient fingerprint recognition algorithm using phase-based image matching. The use of phase components in $2 \mathrm{D}$ discrete Fourier transforms of fingerprint images makes possible to achieve highly robust fingerprint recognition for low-quality fingerprints. However, due to its high computational complexity, the proposed algorithm is not suitable to be implemented in compact fingerprint matching devices for home applications. In this paper, we propose an improved fingerprint recognition algorithm using phase-based image matching, which significantly reduces computational complexity without degrading recognition performance, compared with the reported algorithm. We also present prototype implementation of a high-performance, easy-to-use fingerprint matching device for home applications, which employ a specially designed ASIC for executing the proposed algorithm in real time.

キーワード：バイオメトリクス, 個人認証, 指紋照合 , 位相限定相関法

Keywords : Biometrics, Personal Authentication, Fingerprint Matching, Phase-Only Correlation

\footnotetext{
* 株式会社 山武

T 259-1195 神奈川県伊勢原市鈴川54

Yamatake Corporation,

54, Suzukawa, Isehara, Kanagawa, 259-1195, Japan

** 東北大学大学院情報科学研究科

T 980-8579 宮城県仙台市青葉区荒巻字青葉 6-6-05

Graduate School of Information Sciences, Tohoku

University,

Aoba 6-6-05, Aramaki-aza, Aoba-ku, Sendai, Miyagi

980-8579, Japan

$* * *$ 東北工業大学工学部

T 980-8579 宮城県仙台市太白区八木山香澄町 35-1

Faculty of Engineering, Tohoku Institute of Technology,

35-1 Kasumi-cho, Yagiyama, Taihaku-ku, Sendai, Miyagi

982-8579, Japan
}

\section{1. まえがき}

近年 , バイオメトリクスによる個人認証は, さまざまな 応用においてセキュリティ確保に欠くことのできない技術 として認知されつつある。特に指紋照合は, 他のバイオメ トリクス認証に比べ, 装置の小型化が可能であり, 価格も 安く, 認証性能も高いので最も実用化が進んでいる(1) (2)。 現在の指紋照合技術では, 一般に, 多くの標準的なユー ザーは問題なく使用できるものの, 全体の数パーセント程 度のユーザーは照合が難しい指紋を有すると言われ, 製品 化の際の問題となっている。このような指紋の持ち主は, 
アレルギー性皮膚炎の人や家事などによって肌荒れしやす い主婦，肌が乾燥しやすい高齢者などに多い。一般に，肌 の乾燥や濡れによる指紋画像の乱れについては, 感圧セン サ(3)の使用によってある程度の改善が可能である。しかし，

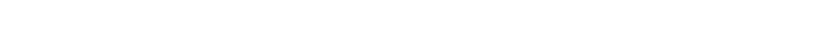
減りと再生を繰返している状態であり，指紋画像上では， 隆線か部分的に切れたり潰れたりするため，本人認証が難 しい。この問題を解決するためには，照合アルゴリズム自 体の検討が必要であると考えられる。

このような観点から，筆者らは，現在までに，位相限定 相関法(Phase-Only Correlation: POC)と呼ぶ画像マッチン グ手法を用いた指紋照合アルゴリズムを提案している(4)(5)。 位相限定相関法は, サブピクセル精度の位置ずれ検出が可 能な画像マッチング手法であり，コンピュータビジョンの 応用において有用性が示されている(6)(7)(8)。近年, 筆者らは， 指紋画像の有効帯域を選択的に抽出して照合を行うことが できる帯域制限位相限定相関法 (Band-Limited Phase-Only Correlation: BLPOC) を提案し(5)，劣化した指 紋画像の照合に対して有効であることを確認している。一 般に，特徵点抽出に基づく通常の指紋照合手法は(9)，肌荒れ などによって紋樣が乱れている場合, 特徵点を正確に抽出 できないことが多く照合精度が大幅に低下する。これに対 して，帯域制限位相限定相関法は，画像全体の位相情報を 用いた照合手法であり，劣化に対してロバストである(5)。

一方，特徵点方式と異なり，帯域制限位相限定相関法に 基づく指紋照合アルゴリズムは，2 次元 FFT（高速フーリ 工変換) などの計算量が問題になり，通常の組み込みコン ピュータによるリアルタイム処理は困難である。特に，認 証性能を重視して指紋画像のサイズを増加させると処理速 度が低下する。すなわち, 認証性能と処理速度はトレード オフの関係にあり，一般に，処理速度を優先すれば，認証 性能を犠牲にして演算量を減らすことになる場合が多いと 考えられる。

本論文では，主婦や高齢者のユーザーが多い一般住宅の アクセス管理に使用することを目標に，帯域制限位相限定 相関法の認識性能を維持しつつ, 演算量を大幅に削減した 製品向きの指紋照合アルゴリズムを提案する。従来のアル

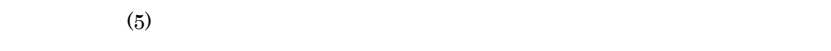
たフーリエ変換を使用していたが, 提案するアルゴリズム では，入力画像を最適なサイズに縮小することによって， ほぼ同等の効果が得られることを明らかにし，大幅に演算 量を減少させた。さらに，相関ピークから照合スコアを算 出する際の新しい計算方法を開発し, 状態が悪い指紋を含 むデータベースを用いた性能評価を通して有効性を確認し た。

提案する照合アルゴリズムは, 帯域制限型のアルゴリズ 厶 ${ }^{(5)}$ と同等の認証性能を実現する一方で,計算量が少なく固 定サイズの 2 次元 FFT のみを使用するため，LSI による高 速化に適している。本論文では，提案手法を実時間処理す るための専用 LSI を開発した結果を示す。この LSI をコア
とし，感圧センサを組合せた一般住宅向きのユーザーフレ ンドリーな指紋照合式ドア制御装置のプロトタイプを試作 した。通常の特徵点べースの指紋照合装置と比較して, 条 件の悪い指紋に対してもロバストな認証が可能であり，さ らに専用 LSI の採用によって, きわめて高速な認証を実現 している。

\section{2. 位相限定相関法に基づく指紋照合アルゴ リズム}

$\langle 2 \cdot 1\rangle$ 位相限定相関関数 まず, 位相限定相関関数 (POC 関数) の定義を示す。いま, $N_{1} \times N_{2}$ の 2 つの画像 $f\left(n_{1}, n_{2}\right)$ と $g\left(n_{1}, n_{2}\right)$ を考える。ここで, 簡単化のために画素 のインデックスの範囲を正の整数 $M_{1}$ および $M_{2}$ を用いて， $n_{1}=-M_{1} \cdots M_{1}, n_{2}=-M_{2} \cdots M_{2}$ とする。すなわち $N_{1}=2 M_{1}+1$, $N_{2}=2 M_{2}+1$ である。このとき , 画像 $f\left(n_{1}, n_{2}\right)$ および $g\left(n_{1}, n_{2}\right)$ の 2 次元離散フーリエ変換 (2 次元 DFT) $F\left(k_{1}, k_{2}\right)$ および $G\left(k_{1}, k_{2}\right)$ は次式で与えられる。

$$
\begin{aligned}
F\left(k_{1}, k_{2}\right) & =\sum_{n_{1}=-M_{1}}^{M_{1}} \sum_{n_{2}=-M_{2}}^{M_{2}} f\left(n_{1}, n_{2}\right) W_{N_{1}}^{k_{1} n_{1}} W_{N_{2}}^{k_{2}, n_{2}} \\
& =A_{F}\left(k_{1}, k_{2}\right) e^{j \theta_{F}\left(k_{1}, k_{2}\right)} \ldots \ldots \ldots \ldots \ldots \ldots \ldots \ldots \ldots \ldots \ldots \ldots
\end{aligned}
$$

ここで $k_{1}=-M_{1} \cdots M_{1-j} k_{2}=-M_{2} \cdots M_{-j}$ は周波数インデック スであり, $W_{N_{1}}=e^{-j \frac{N_{1}}{N_{1}}}$ と $W_{N_{2}}=e^{-j \frac{N_{2}}{N_{2}}}$ は回転因子である。 $A_{F}\left(k_{1}, k_{2}\right)$ と $A_{G}\left(k_{1}, k_{2}\right)$ は振幅成分, $e^{j \theta_{F}\left(k_{1}, k_{2}\right)}$ と $e^{j \theta_{G}\left(k_{1}, k_{2}\right)}$ は位 相成分を表す。

このとき， $F\left(k_{1}, k_{2}\right)$ と $G\left(k_{1}, k_{2}\right)$ の合成位相スペクトル $\hat{R}_{F G}\left(k_{1}, k_{2}\right)$ を次式で定義する。

$$
\begin{aligned}
& \hat{R}_{F G}\left(k_{1}, k_{2}\right)=\frac{F\left(k_{1}, k_{2}\right) \overline{G\left(k_{1}, k_{2}\right)}}{\left|F\left(k_{1}, k_{2}\right) \overline{G\left(k_{1}, k_{2}\right)}\right|} \\
& =e^{j \theta\left(k_{1}, k_{2}\right) \cdots}
\end{aligned}
$$

ここで $\overline{G\left(k_{1}, k_{2}\right)}$ は $G\left(k_{1}, k_{2}\right)$ の複素共役を表し， $G\left(k_{1}, k_{2}\right)$ で ある。位相限定相関関数 (POC 関数) $\hat{r}_{f g}\left(n_{1}, n_{2}\right)$ は $\hat{R}_{F G}\left(k_{1}, k_{2}\right)$ の 2 次元離散フーリエ逆変換 ( 2 次元 IDFT) として定義さ れる。

$$
\begin{aligned}
& \hat{r}_{f g}\left(n_{1}, n_{2}\right) \\
& \quad=\frac{1}{N_{1} N_{2}} \sum_{k_{1}=-M_{1}}^{M_{1}} \sum_{k_{2}=-M_{2}}^{M_{2}} \hat{R}_{F G}\left(k_{1}, k_{2}\right) W_{N_{1}}^{-k_{1} n_{1}} W_{N_{2}}^{-k_{2} n_{2}}
\end{aligned}
$$

2 つの同じ画像の POC 関数は, 常にクロネッカーのデル 夕関数となる。この相関ピークの急峻な特性を利用すると， 指紋画像の照合などの応用で通常の相関関数と比較して, 高い識別性能を実現することができる。画像の位置ずれは 相関ピークの位置のみに反映され，相関ピークの形状には 影響を与えないという特長がある。また , スペクトルの振 幅成分を使わないので, 輝度変化に影響されにくい。ただ 
し，画像の回転には大きな影響を受けるので，指紋画像の 回転を正規化する必要がある。

一般に指紋画像は，弚の紋に対応する固有の周波数以下 の成分に重要な情報を有する。兰れ以外の高周波成分は工 ネルギーが小さく，乥の位相情報は相関を計算する際の外 乱として働き，識別性能を低下させることが実験的に判明 している。乥こで，指紋画像の有効な周波数成分のみを抽 出して照合するために, 次式で与えられる帯域制限位相限 定相関関数 (BLPOC 関数) が提案されている ${ }^{(5)}$ 。

$$
\begin{aligned}
\hat{r}_{f g}^{K_{1}, K_{2}} & \left(n_{1}, n_{2}\right) \\
& =\frac{1}{L_{1} L_{2}} \sum_{k_{1}=-K_{1}}^{K_{1}} \sum_{k_{2}=-K_{2}}^{K_{2}} \hat{R}_{F G}\left(k_{1}, k_{2}\right) W_{N_{1}}^{-k_{1} n_{1}} W_{N_{2}}^{-k_{2} n_{2}}
\end{aligned}
$$

ここで， $K_{1}\left(0<K_{1} \leq M_{1}\right)$ および $K_{2}\left(0<K_{2} \leq M_{2}\right)$ は指紋画像 の有効周波数の上限である。また， $L_{1}=2 K_{1}+1 ， L_{2}=2 K_{2}+1$ ， $n_{1}=-K_{1} \cdots K_{1}, n_{2}=-K_{2} \cdots K_{2}$ である。BLPOC 関数は, 制限 する周波数帯域 $K_{1}$ および $K_{2}$ に依存せず, 常に相関ピークの 最大值が1に正規化される。また，BLPOC 関数は通常の POC 関数と比較して高い識別性能を有するが， 2 次元離散 フーリエ逆変換のサイズが指紋の固有周波数 $K_{1}$ および $K_{2}$ により変化するため, 専用ハードウェアによる実装は必ず しも容易ではない。

〈2·2〉指紋照合アルゴリズム＼cjkstart図 1(a)にBLPOC 関 数を用いた指紋照合アルゴリズムを示す(5)。本論文では，こ のアルゴリズムと同レベルの認証性能を実現しつつ, 計算 の複雑さを大幅に低下させたアルゴリズムを提案する。 BLPOC 関数を用いたアルゴリズムにおいて, 弚の認証性能 を決定する重要な処理は，図 1(a)のステップ 6 であり，光

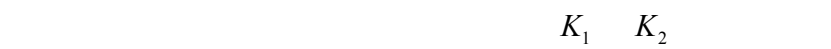
えで, 光の周波数範囲において帯域制限位相限定相関関数 $\hat{r}_{f g^{\prime \prime} g_{2}}^{K_{1} K_{2}}\left(n_{1}, n_{2}\right)$ を計算することが重要である。ここで, $K_{1}$ と $K_{2}$ は弚れ光れの指紋画像ごとに適応的に決定される。さらに， ステップ 5 で共通領域抽出された指紋画像の大きさも画像 ごとに異なる。このため，本アルゴリズムにおいては， $\hat{r}_{f^{\prime} g}^{K_{1} K_{2}}\left(n_{1}, n_{2}\right)$ の計算の際に必要となる 2 次元離散フーリエ変 換の順変換 (式(1)，(2)）と逆変換 (式(5)) の点数力指紋画 像ごとに異なり，光のハードウェア化は必ずしも容易では ない。

一方，筆者らの想定している指紋センサ (BMF 社製感圧 式センサ BLP-100 ，画像サイズ $384 \times 256$ 画素) (3)を用い て多数の評価実験を行った結果， $K_{1}$ と $K_{2}$ の值は，ほぼ 0.4 〜0.6 の範囲に分布していることが判明しており，これらを 0.5 近傍の定数としても, 認証性能の劣化は少ないことが考 えられる。また，周波数領域での帯域制限の効果は，原画 像の縮小操作 (本実験の場合は縮小率 0.5 程度) によって置 き換えることが可能であると考えられる。光こで，以下で は，次のような方針によってアルゴリズムの大幅な簡単化 を行う。(i)入力画像を一定の割合 $S(\leq 100 \%)$ でスケーリン グ (縮小) する。(ii） 2 次元離散フーリエ変換の順変換と逆 変換のサイズをすべて固定サイズとする。(iii)兴の他 , 共通
領域抽出を簡単化するとともに照合スコアの算出法を改良 する。

以上の方針によって簡単化されたアルゴリズムを図 1(b) に示す。基本的な処理の内容は，次の通りである。

(i ) 画像縮小処理

BLPOC 関数の帯域制限効果を入力画像の縮小処理 (縮小率 $S ）$ によって置き換えることによって，通常の P P 関数の 1 回の計算によって照合を行う。センサより得られた 384 $\times 256$ 画素の指紋画像間のPOC関数を計算すると, 高周波帯 域にある信頼性の低い位相データの影響を受けるため，認 証性能は悪くなると考えられる。これに対して, 縮小処理 を行うと信頼性の低い位相データの影響を抑えられるの で, 認証性能はよくなると考えられる。ただし, 画像を縮 小し過ぎると指紋パターンの解像度が低くなり，パターン が潰れはじめるので, 認証性能は悪くなると考えられる。 光のため, 信頼性の低い位相データを除去しつつ, 認証性

能が低下しないように, 画像縮小率 $S$ を実験的に最適化 することによって, 認証性能は向上すると予想される。こ の方法は, 低解像度のセンサにも対応しやすく,縮小率 $S$ を パラメータとした最適化により，ほぼBLPOC の帯域制限 効果と同等の効果が期待できる。センサが出力する画像は $384 \times 256$ 画素であるが，照合に用いる画像サイズは計算量 の観点から $128 \times 128$ 画素とした。指紋画像全体を $S$ 倍に縮 小し,指紋画像の重心を中心として $128 \times 128$ 画素の領域を 抽出して使用する。

（ii） 2 次元離散フーリ工変換（順変換と逆変換）におけ るサイズの固定

提案するアルゴリズムでは,BLPOC 関数を用いた場合の ように指紋画像ごとに順変換と逆変換のサイズが変化する ことがなく，固定サイズ $(128 \times 128)$ の POC 関数のみで 照合を実行する。このため, 固定サイズの FFT を基本とす る専用ハードウェアによる実現に適している。

（iii） 照合スコアの算出法の改良

POC 関数の最大相関ピークを中心とした一定領域に着目 し, 大きなピークを上位から数個選び, 最大ピークからの 距離に依存する重みをかけて，弚の大きさを合計したもの をスコアとする。実験では，最大ピークを中心とした $5 \times 5$ 画素の領域を用い, 評価するピーク数は上位 3 個とした。 これら 3 つのピークの值に, 中心からの (距離 +1$)$ の逆数 を重みとしてかけて合計したものをスコアとした。一般に， 他人照合時には, 最大ピークから離れた位置に比較的大き なピークか現れる傾向があり，これを滅点することによっ て他人受入率を下げる効果がある。

$\langle 2 \cdot 3\rangle$ 評価実験とパラメータ最適化評価実験で は, 性能の差を明確にするために, 意図的に指紋の状態が 悪く照合が困難なユーザーのデータを収集して使用した。 被験者は 12 名であり, うち男性 8 名, 女性 4 名である。指 紋の状態で分類すると, 状態が良好な人が 7 名, 乾燥肌の ために照合に多少の困難がある人 3 名 ,肌荒れのひどい人 1 名，アトピー性皮膚炎の人 1 名という構成である。各被験 
1. Repeat the following process over the angular range $-20^{\circ} \leq \theta \leq 20^{\circ}$ with an angel spacing $1^{\circ}:$

- Generate the rotated image $f_{\theta}\left(n_{1}, n_{2}\right)$ of the registered fingerprint image $f\left(n_{1}, n_{2}\right)$.

- Calculate the POC function $\hat{r}_{f_{\theta} g}\left(n_{1}, n_{2}\right)$ between $f_{\theta}\left(n_{1}, n_{2}\right)$ and $g\left(n_{1}, n_{2}\right)$.

2. Determine the rotation angle $\Theta$ by evaluating the similarity using the POC function $\hat{r}_{f_{\theta} g}\left(n_{1}, n_{2}\right)$ to select the rotation-normalized image $f_{\Theta}\left(n_{1}, n_{2}\right)$.

3. Estimate image displacements $\left(\tau_{1}, \tau_{2}\right)$ between $f_{\Theta}\left(n_{1}, n_{2}\right)$ and $g\left(n_{1}, n_{2}\right)$ from the peak location of $\hat{r}_{f_{\ominus} g}\left(n_{1}, n_{2}\right)$.

4. Align the translational displacement $f_{\Theta}\left(n_{1}, n_{2}\right)$ and $g\left(n_{1}, n_{2}\right)$ to obtain the normalized images $f^{\prime}\left(n_{1}, n_{2}\right)$ and $g^{\prime}\left(n_{1}, n_{2}\right)$.

5. Extract the common regions $f^{\prime \prime}\left(n_{1}, n_{2}\right)$ and $g^{\prime \prime}\left(n_{1}, n_{2}\right)$ from $f^{\prime}\left(n_{1}, n_{2}\right)$ and $g^{\prime}\left(n_{1}, n_{2}\right)$.

6. Detect the inherent frequency band $\left(K_{1}, K_{2}\right)$ from the 2D DFT of $f^{\prime \prime}\left(n_{1}, n_{2}\right)$.

7. Calculate the BLPOC function $\hat{r}_{f^{\prime \prime} g^{\prime \prime}}^{K_{1} K_{2}}\left(n_{1}, n_{2}\right)$ and compute the matching score as the sum of the highest two peaks of calculated BLPOC function.

(a)

1. Scale $f\left(n_{1}, n_{2}\right)$ and $g\left(n_{1}, n_{2}\right)$ to $S \%$ of their image sizes and extract

$128 \times 128$-pixel images, from the scales images, centered at the center of gravity.

2. Repeat the following process over the angular range $-20^{\circ} \leq \theta \leq 20^{\circ}$ with an angel spacing $1^{\circ}:$

- Generate the rotated image $f_{\theta}\left(n_{1}, n_{2}\right)$ of the registered fingerprint $f\left(n_{1}, n_{2}\right)$.

- Calculate the POC function $\hat{r}_{f_{\theta} g}\left(n_{1}, n_{2}\right)$ between $f_{\theta}\left(n_{1}, n_{2}\right)$ and $g\left(n_{1}, n_{2}\right)$.

- Calculate the matching score by using the improved score calculation

method.

3. Obtain the final matching score as the maximum value of the calculated matching scores.

(b)

図 1 指紋照合アルゴリズムのフロー : (a) BLPOC 関数を用いた照合アルゴリズム , (b) 提案する照合アルゴリズム

Fig. 1. Flow diagram of fingerprint matching algorithms: (a) BLPOC-based matching algorithm and (b) proposed algorithm.

者より 10 枚の指紋画像を取得し，合計で 120 枚の指紋画像 を用いた。評価実験は，次の組合せで行った。

・ 本人同士の照合の組合せ : ${ }_{10} \mathrm{C}_{2} \times 12=540$ 組

- 他人同士の照合の組合せ : ${ }_{120} \mathrm{C}_{2}-540=6600$ 組 認証性能を定量的に評価するために, 下記のパラメータ を定義しておく。

- FNMR (False Non-Match Rate): 本人を間違って他 人として拒否してしまう本人拒否率。FNMR が小さい ほど性能が高い。

- FMR (False Match Rate): 他人を間違って本人とし
て受け入れてしまう他人受入率。FMR が小さいほど性 能が高い。

- EER (Equal Error Rate): FNMR と FMR が等しくな るときの誤り率。EER が小さいほど性能が高い。

- ZeroFMR：他人を間違って本人として受け入れること がないように閾値を設定した場合 $(\mathrm{FMR}=0 \%)$ の最小 の FNMR。

以下では, 画像縮小処理が BLPOC 関数の帯域制限効果 と同等の効果があることを検証した実験 (実験 1) と，一般 的によく用いられている特徵点を用いた照合アルゴリズム 
と性能を比較した実験（実験 2) について述べる。

(実験 1) 画像縮小処理の効果とパラメータ最適化

提案手法 (図 1(b)) における画像縮小の効果を検証する ために，作成した指紋画像データベースに基づいて照合実 験を行った。実験では，提案アルゴリズムの縮小率 $S$ を最 適化するために，S $30 \%$ から $100 \%$ まで $5 \%$ 刻みで変化さ せた。図 2(a)および(b)は, 縮小率 $S$ に対する EER および ZeroFMR を光れぞれプロットしたものである。最大相関ピ 一ク值を谷のまま照合スコアとした場合と，改良したスコ ア算出法により得られた照合スコアを用いた場合を比較し ている。また，比較のために，BLPOC 関数を用いた照合ア ルゴリズム (図 1(a)) における EER と ZeroFMR を点線で 示す。実験結果より，縮小率 $S$ を $45 \%$ と設定し，改良した スコア算出法を用いた場合の性能が最適であった。この場 合の EER と ZeroFMR は, BLPOC 関数を用いた照合アル ゴリズムにおける值にほぼ等しいことより，画像縮小は， BLPOC 関数の帯域制限と同等の効果があることを示して いる。

今回のセンサは, 画像サイズ $384 \times 256$ 画素, 解像度 500dpi のものを用いたが , 提案手法は他のセンサにも応用 可能と考えている。実験結果より, 最適な縮小率は $45 \%$ と 判明したので，指紋画像の解像度は原画像の解像度 500dpi に 0.45 をかけた $225 \mathrm{dpi}$ が最適となる。この $225 \mathrm{dpi} へ の$ 縮 小処理により，指紋画像の固有周波数を含み，かつ，信頼 性の低い高周波の位相成分の少ない最適な指紋画像が得ら れる。他のセンサに応用する場合も同樣に，指紋画像を $225 \mathrm{dpi}$ 程度に画像を縮小して 重心を中心とした $128 \times 128$ 画素で抽出すれば同樣な結果が得られると考えられる。

(実験 2) 性能比較実験

照合アルゴリズムの性能を比較するために，(A) 特徵点を 用いた照合アルゴリズム (一般に市販されているもの)，(B) BLPOC 関数を用いた照合アルゴリズム（図 1(a))，(C) 実 験 1 で最適化した提案手法の 3 つを用いて照合実験を行っ た。性能比較には, ROC (Receiver Operating Characteristic）曲線と EER, ZeroFMR を用いる。 ROC 曲線とは，照合スコアの適当な閾值における FNMR と FMR を表した曲線である。3つの照合アルゴリズムの ROC 曲線 と EER，ZeroFMR を図 3 に示す。実験結果より，BLPOC 関数を用いた照合アルゴリズム $\mathrm{B})$ と提案するアルゴリズム (C)は，特徵点を用いた照合アルゴリズム(A)と比較して，光 の ROC 曲線が FNMR/FMR の低い場所に位置しているの で,より高性能であることが分かる。また，EER は，提案

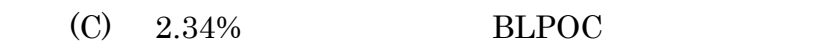
合アルゴリズム $(\mathrm{B})$ が $2.46 \%$, 特徵点を用いた照合アルゴリ ズム(A)が 7.34\%である。ZeroFMR は 提案手法(C)が $4.26 \%$ であるのに対し，BLPOC 関数を用いた(B)が $5.00 \%$, 特徵

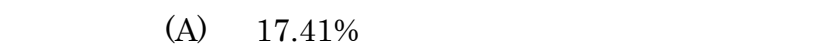
指紋の状態が悪く照合が困難な指紋画像に対して BLPOC 関数を用いた照合アルゴリズムと同樣に有効である。

さらに, 提案手法は, 固定サイズ $(128 \times 128)$ の 2 次元

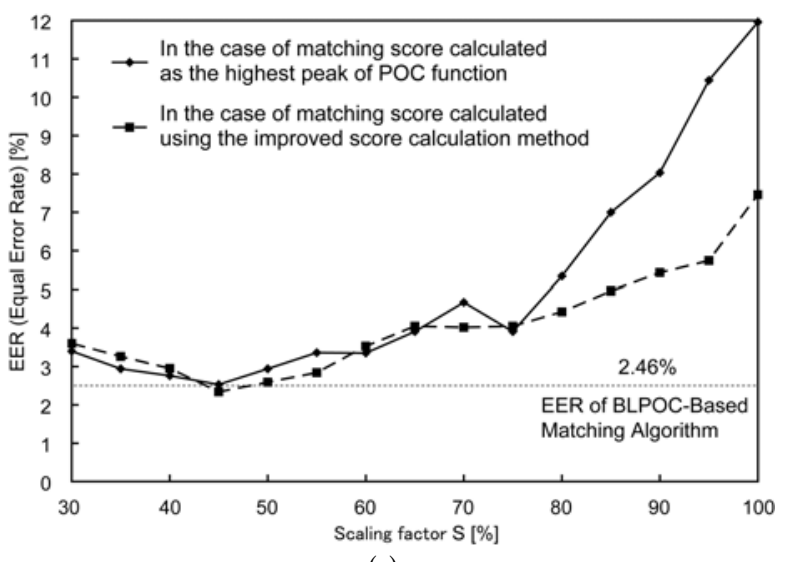

(a)

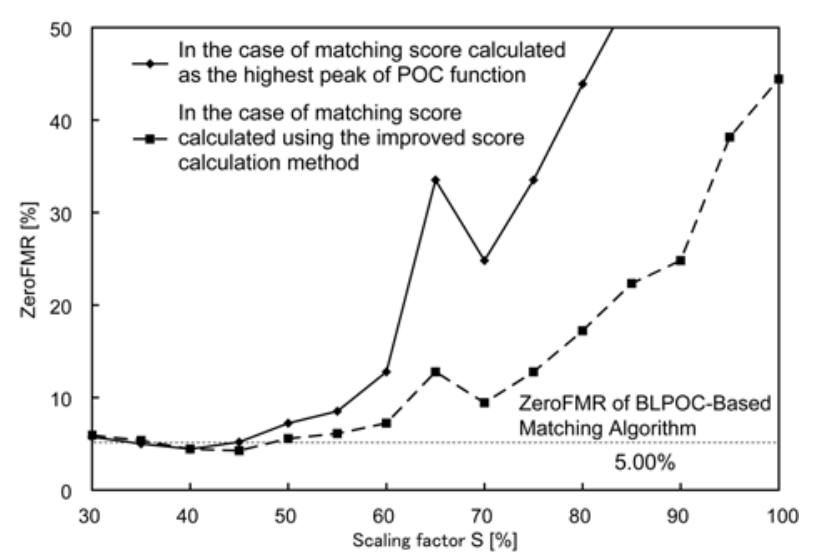

(b)

図 2 提案アルゴリズムの縮小率 $S$ を変化させたときの EER (a)と ZeroFMR (b)

Fig. 2. EER (a) and ZeroFMR (b) as the scaling factor $S$ changes.

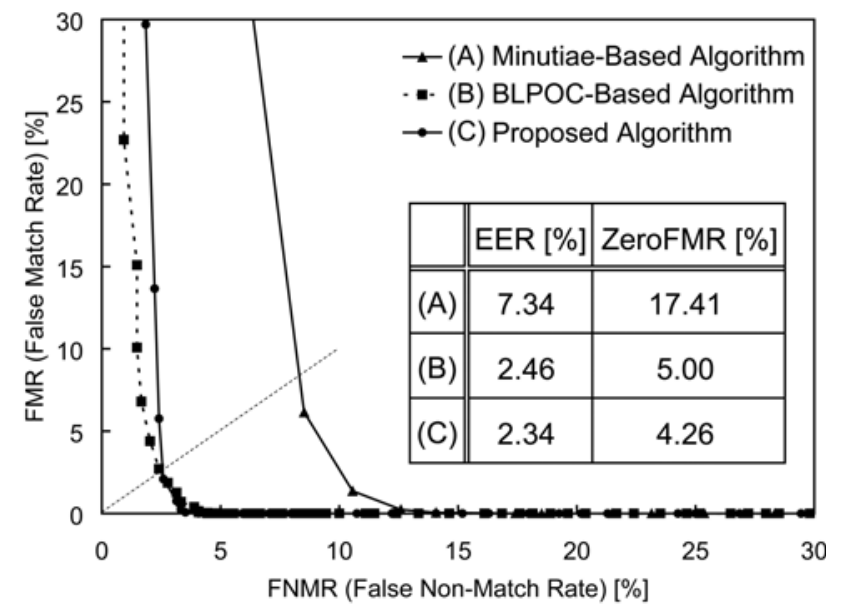

図 3 ROC 曲線によるアルゴリズムの評価

Fig. 3. ROC curves, EERs and ZeroFMRs.

FFT のみを使用するとともに, 光の他の処理を簡単化する ことによって, BLPOC 関数を用いた手法と比較して, 計算 の複杂隹さを大幅に減少している。一例として, 計算機実験 
( CPU: Pentium4 3.0GHz, Memory: 1GB, MATLAB $7.01)$ によ実行時間を評価した結果，BLPOC 関数を用い た手法の処理時間は 19.07 秒であるのに対して，提案手法 の処理時間はわずか 2.45 秒であった。すなわち，提案手法 は,BLPOC 関数を用いた照合アルゴリズムと同レベルの認 証性能を実現しつつ, 計算の複杂隹さを大幅に減少させるこ とに成功している。

\section{3. 専用 LSI の実現}

位相限定相関法はそ次処理の規則性により専用 LSI によ る実現にきわめて適している。すでに，筆者らの研究グル ープでは, 工業市場向けの画像認識装置の実用化に際して， 位相限定相関法の専用 LSI を開発した実績を有してい

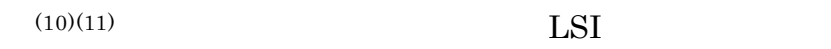
いても報告されている(12)。本論文で取り上げる一般住宅向 けの指紋認証装置においても，利便性の向上の観点から， 位相限定相関法の高速処理を実現する専用 LSI の開発は不 可欠である。図 4 に開発した専用 LSI を示す。本 LSI は指 紋センサ ,ホスト CPU ,PBSRAM (Pipelined Burst Static Random Access Memory) などとのインターフェースを備 え, 部品点数を大幅に削減するとともに基板を小型化でき る利点を提供する。

図 5 に専用 LSI のブロック図を示す。応答時間の短縮に よるユーザーの利便性を向上させるため, 内部では徹底的 なパイプラインアーキテクチャを採用している。各ブロッ クの処理内容を次に示す。

- CPU Interface: CPU(SH3/7709A)とのインターフェ ースを行う。

- SRAM Interface: ローカルメモリ(PBSRAM)へのア クセスを行う。

- CCD Camera Capture Interface: CCD をはじめとす る画像入力に関わるインターフェースを行う。画像情 報はここから入力される。

- Resize：画像縮小処理部。入力された画像の情報を指 定されたサイズに縮小し，内部メモリに書き込む。入 カ系のダイナミックレンジ , およびオフセットを調整 する機能も含まれている。

- Memory Blocks: 内部メモリブロック (384 bits× 4 banks，デュアルポート同期 SRAM) である。FFT 処 理のためのバッファなどとして利用される。4 つの独

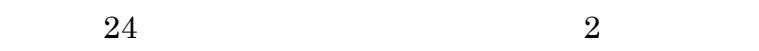

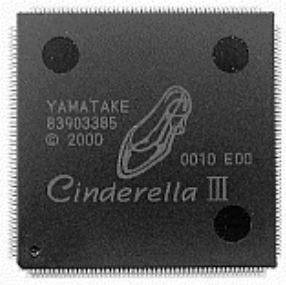

図 4 位相限定相関法専用 LSI の外観

Fig. 4. LSI for phase-only correlation.
た 48 ビット幅デュアルポートメモリとしての利用も 可能である。

- FFT Unit: FFT 演算処理部。内部メモリ 2 バンクを用 いて 128 点 FFT の計算を実行する。

- Pre-Processing Controller: ローカルメモリ (PBSRAM) と前処理部とのインターフェースを行う。 専用 LSI からローカルメモリ(PBSRAM)へリードする アドレスを計算して SRAM Interfaceヘリード要求を 行い, ローカルメモリ(PBSRAM)に格納されているデ 一タを前処理部入渡す。

- Subtractor: 減算部。画像間の差分，オフセット除去 などの減算処理を行う。飽和処理, ゲイン調整も行う。

- Phase to Complex Converter: 8 ビットの位相データ を 16 ビットの複素数 (直交座標表現) に変換する。

- Post-Processing Controller: 内部メモリに蓄積されて

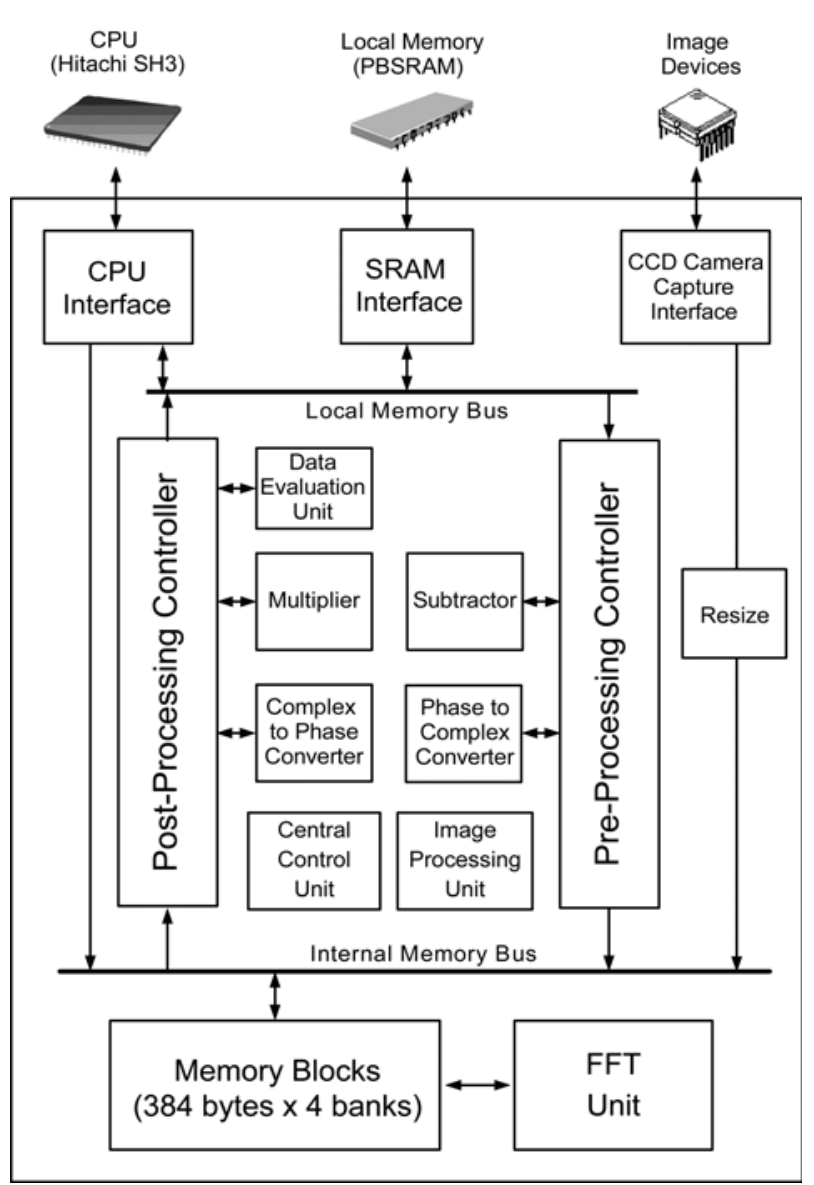

図 5 専用 LSI 内部ブロック図

Fig. 5. Block diagram of the developed LSI.

表 1 LSI 仕樣

Table 1. LSI specification.

\begin{tabular}{|l|l|}
\hline Process & $0.35 \mu \mathrm{m} \mathrm{CMOS} \mathrm{Gate} \mathrm{Array}$ \\
\hline Operating Frequency & $57 \mathrm{MHz}$ \\
\hline Package & QFP 208 pins \\
\hline Power & $3.3 \mathrm{~V} \pm 0.3 \mathrm{~V}$ \\
\hline Internal Memory & $3 \mathrm{kbits} \times 4$ banks \\
\hline POC Processing Time & $8.8 \mathrm{~ms}(128 \times 128$-pixel) images \\
\hline
\end{tabular}


いるデータを後処理部へ渡す。

- Image Processing Unit: 複素数の絶対値計算, 画像の $\log$ 変換などの処理を行う。

- Data Evaluation Unit: 画像評価に利用するための輝 度值の平均・有効面積などを計算する。画像内での評 価エリアも指定できる。

- Multiplier：乗算部。画像に空関数を適用するための乗 算などを行う。

- Complex to Phase Converter: 24 ビットの複素数デー 夕 (直交座標表現) を 8 ビットの位相データに変換す る。

- Central Control Unit: 中央制御部。画像取り込みや演 算の処理ステートを管理し,データフローを制御する。 消費電力を抑えるための制御も行う。

表 1 にLSI の基本仕樣を示す。128x128 画素の指紋画像 に対する位相限定相関関数の計算時間は, $57 \mathrm{MHz}$ 動作で約 $8.8 \mathrm{msec}$ である。同じ計算を PC (CPU: Pentium4 3.0GHz, Memory：1GB, MATLAB 7.01) で実行すると，平均約 $28 \mathrm{msec}$ であった。開発した LSI は, 約 $1 / 53$ の周波数動作 でありながら，約 3 倍の高速処理を達成している。

\section{4. 一般住宅向け指紋照合装置の試作}

乾燥肌や肌荒れに悩むユーザーも含め，万人が使用でき る利便性の高い指紋照合装置の開発を目指し，提案した専 用 LSI をコアとして感圧センサを組合せた一般住宅向き指 紋照合式ドア制御装置のプロトタイプを試作した（図 6)。 通常の特徵点べースの指紋照合装置と比較して, 条件の悪 い指紋に対してもロバストな認証が可能であり，さらに専 用 LSI の採用によって，きわめて高速な認証を実現してい る。

このプロトタイプは, 指紋登録・照合を行う照合ユニッ トと電気錠のコントロールを行う制御ユニットの 2 ピース
構成とした。照合ユニット (図 6(a)) の外形寸法は, 120× 160× 70 (W,H,D) mm である。電源として制御ユニットに $\mathrm{AC} 100 \mathrm{~V}$ を入カし, 照合ユニットには制御ユニットから $\mathrm{DC} 24 \mathrm{~V}$ を供給する。照合ユニットは，指紋照合により本人 が確認されると，RS485 経由で制御ユニットに解錠信号が 送られる。制御ユニットは, 解錠信号を受け電気錠を解錠 する。電気錠は, 通電時解錠型, 通電時施錠型, モ一夕錠 などほとんどのタイプに対応している。

照合ユニットは，指ガイドを備えることにより指が回転 しにくい構造とし，指紋照合における回転補正を- $12^{\circ} \sim 12^{\circ}$ の角度範囲に対応するように設計した（上記で評価したア ルゴリズムでは- $20^{\circ} \sim 20^{\circ}$ としていたが , 指ガイドの導入に より，探索する角度範囲を制限しても性能が低下しないこ とを確認している)。この結果, 位相限定相関法の専用 LSI の採用により，1 指あたりの指紋照合処理全体をわずか 0.1 秒程度で実行することが可能になった。さらに，20 指紋登 録時には約 2 秒で電気錠を解錠できる。

本プロトタイプには, 以上の機能のほかに，一般住宅の ユーザーに対して利便性を向上させるためのユーザーイン ターフェースとして, 取り込んだ指紋画像をリアルタイム に表示する機能，ならびに，指紋の登録・照合の際のユー ザーの習熟度を算出して表示する機能を備えている。また， ユーザーの指の置き方の変化を吸収するために, 登録指紋 画像を自動更新する機能を実現している。これらの諸機能 とともに，指紋画像の劣化に対して本質的にロバストな「位 相限定相関法」の採用により，高齢者・主婦・子供など， 年齢や性別を問わずに，広く一般家庭で利用できる新しい コンセプトのバイオメトリクス技術を確立するための第一 歩が実現できたと考えられる。

\section{5. まとめと今後の展望}

今後, バイオメトリクス技術が, 一般住居なども含め,

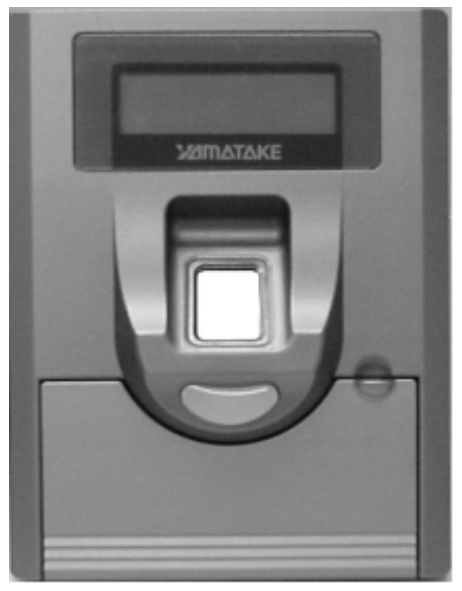

(a)

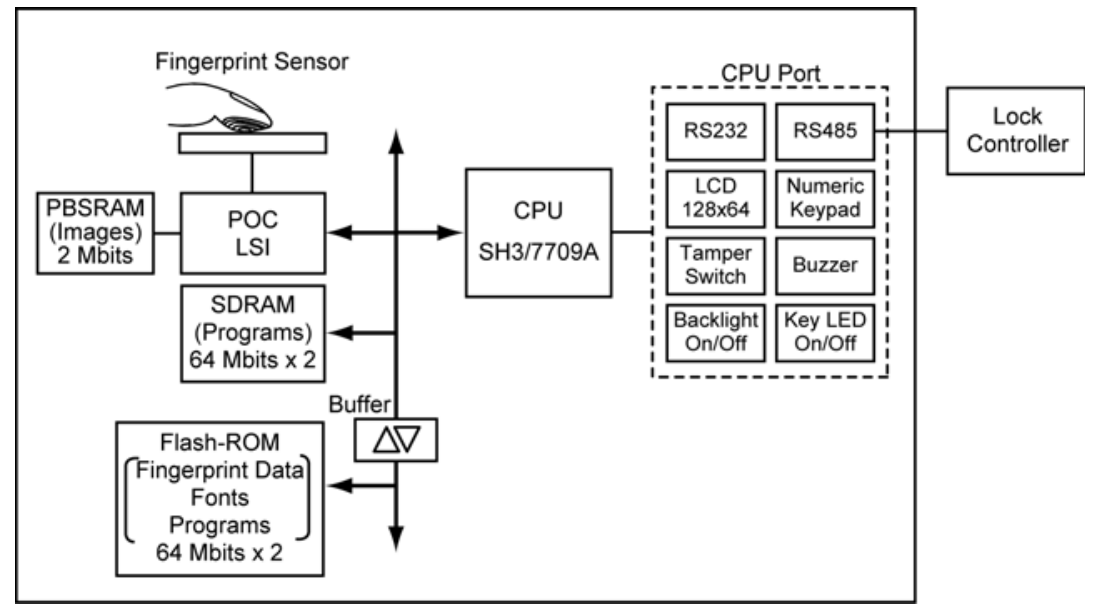

(b)

図 6 指紋照合式ドア制御装置のプロトタイプ: (a) 外観, (b) ハードウェア構成

Fig. 6. Prototype of the fingerprint matching device: (a) its appearance and (b) its hardware configuration. 
広く社会に浸透するためには，万人にとって利用しやすい という意味での「ユニバーサルデザイン」の視点に配慮す るとともに，これを具体化する新技術の開発が不可欠であ る。このような観点から，本論文では，指紋の劣化にロバ ストな位相限定相関法に基づく指紋照合アルゴリズムを提 案した。評価実験では，指紋の状態が悪い人 5 人を含む 12 人のデータベースを用いた評価において，指紋の特徵点を

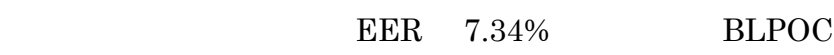
関数を用いた照合アルゴリズムでは $2.46 \%$ ，提案手法では $2.34 \%$ とった。提案手法は，指紋の状態が悪く照合が困難 な指紋画像に対して BLPOC 関数を用いた照合アルゴリズ ムと同樣に有効であることを明らかにした。さらに，演算 時間は,BLPOC 関数を用いた照合アルゴリズムの $1 / 8$ 程度 であり，処理もシンプルな固定点数の FFT 演算を主体とす るため LSI 向きであることも示した。さらに, 提案アルゴ リズムを実行する専用 LSI をハードウェアの高速化技術を 駆使して開発した。この LSI をコアとし，感圧センサを組 合せた一般住宅向けの利便性に優れる指紋照合式ドア制御 装置のプロトタイプを試作した。通常の特徵点べースの指 紋照合装置と比較して，条件の悪い指紋に対してもロバス 卜な認証が可能であり，さらに専用 LSI の採用によって， きわめて高速な認証を実現できた。

なお，筆者らは，位相限定相関法が，他のバイオメトリ クス認証技術においてもきわめて有効であることを見出し ている。例えば，これを虹彩認証に適用した結果，きわめ て高い認識性能を達成できることを明らかにしている(13)。 CISIA の虹彩画像データベースを用いた評価実験では，

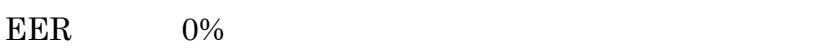
顔の 3 次元情報を用いた個人認証技術に対しても，位相限 定相関法の有効性が明らかになりつつある。すなわち，ス テレオビジョンの対応点探索に位相限定相関法を使用する ことにより，世界ではじめて受動的な 3 次元計測による 3 次元顔照合が可能であることが示されている(14)。位相限定 相関法のサブピクセル精度の対応点探索アルゴリズムを開 発した結果(7) ,カメラから $50 \mathrm{~cm}$ の距離にある顔の 3 次元形 状を $0.6 \mathrm{~mm}$ 程度の精度で倜密に復元可能である。本技術を 18 名の顔認証実験に適用し，EER $=0 \% と い う$ 結果を得てい $3^{(16)}$ 。

以上のように位相限定相関法は，指紋以外にも広範な応 用が可能であり，マルチモーダル認証のための照合エンジ ンとして，さまざまな製品に展開できる可能性を有してい る。

(平成 17 年 6 月 29 日受付, 平成 17 年 10 月 25 日再受付)

\section{文献}

(1) J. Wayman, A. Jain, D. Maltoni, and D. Maio : Biometric Systems, Springer (2005)

(2) D. Maltoni, D. Maio, A.K. Jain, and S. Prabhakar : Handbook of Fingerprint Recognition, Springer (2003)

(3) http://www.bm-f.com/

(4) H. Nakajima, K. Kobayashi, M. Kawamata, T. Aoki, and T. Higuchi : "Pattern Collation Apparatus Based on Spatial Frequency Characteristics (USP5915034)”, US Patent (1995-5)

(5) K. Ito, H. Nakajima, K. Kobayashi, T. Aoki, and T. Higuchi : "A Fingerprint Matching Algorithm Using Phase-Only Correlation”, IEICE Trans. Fundamentals, Vol.E87-A, No.3, pp.682-691 (2004-3)

(6) K. Takita, T. Aoki, Y. Sasaki, T. Higuchi, and K. Kobayashi : "High-Accuracy Subpixel Image Registration Based on Phase-Only Correlation", IEICE Trans. Fundamentals, Vol.E86-A, No.8, pp.925-1934 (2003-8)

( 7 ) K. Takita, M.A. Muquit, T. Aoki, and T. Higuchi : "A Sub-Pixel Correspondence Search Technique for Computer Vision Applications", IEICE Trans. Fundamentals, Vol.E87-A, No.8, pp.1913-1923 (2004-8)

(8) http:/www.aoki.ecei.tohoku.ac.jp/poc/

(9) A.K. Jain, L. Hong, S. Pankanti, and R. Bolle : "An Identity Authentication System Using Fingerprints", Proc. IEEE, Vol.85, No.9, pp.1365-1388 (1997-9)

(10) M. Morikawa, A. Katsumata, and K. Kobayashi : "An Image Processor Implementing Algorithms using Characteristics of Phase Spectrum of Two-Dimensional Fourier Transformation", Proc. IEEE Int. Symp. Industrial Electronics (ISIE), Vol.3, pp.1208-1213 (1999-7)

(11) M. Morikawa, A. Katsumata, and K. Kobayashil : "Pixel-andColumn Pipeline Architecture for FFT-based Image Processor", Proc. IEEE Int. Symp. Circuit and Systems (ISCAS), Vol.3, pp.687-690 (2002)

(12) N. Miyamoto, K. Kotani, K. Maruo, and T. Ohmi : "An Image Recognition Processor Using Dynamically Reconfigurable ALU”, Technical Report of IEICE, ICD2004-123, pp.13-18 (2004-8) (in Japanese)

宮本直人・小谷光司・丸尾和幸・大見忠弘: 「動的再構成 ALU を搭 載した画像認識プロセッサ」信学会技術報告, ICD2004-123, pp.13-18 (2004-8)

(13) K. Miyazawa, K. Ito, T. Aoki, K. Kobayashi, and H. Nakajima : "An Efficient Iris Recognition Algorithm Using Phase-Based Image Matching", Proc. the 2005 IEEE Int. Conf. Image Processing, pp.II-49--II-52 (2005-9)

(14) N. Uchida, T. Shibahara, T. Aoki, H. Nakajima, and K. Kobayashi : "3D Face Recognition Using Passive Stereo Vision", Proc. the 2005 IEEE Int. Conf. Image Processing, pp.II-950-II-953 (2005-9)

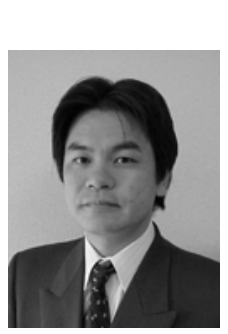

(正員) 1990 年東北大学工学部電子工学科 卒。同年山武ハネウエル(株) (現 , 株式会社山 武) 入社。2003 年同ビルシステムカンパニー開 発本部。現在に至る。主としてバイオメトリク スに関する研究開発,住宅/業務用途の指紋照合 装置の開発に従事。日本自動認識システム協会 バイオメトリクス部会会員。

小林 孝 次

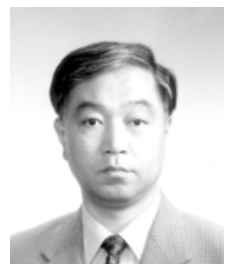

(非会員) 1976 年東北大学工学部電子工学科 卒。1978 年同大学大学院工学研究科電子工学 専攻修士課程卒。同年山武ハネウエル(株) (現， 株式会社山武) 入社, 現在に至る。リアルタイ ム通信プロトコル, 画像処理 , バイオメトリク ス等の研究, 開発に従事。バイオメトリクス開 発室室長。IEEE, 電子情報通信学会, 計測自 動制御学会各会員。 


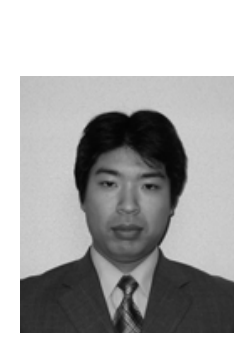

誠 (非会員) 1993 年静岡大学工学部電子工学科 卒業。1995 同大学院工学研究科電子工学専攻 修士課程修了。同年山武ハネウエル(株) (現， 株式会社山武) 入社。現在に至る。主に画像 処理・バイオメトリクス用の LSI 設計や, セン サインタフェイス回路,DSP アプリケーション 開発に従事。

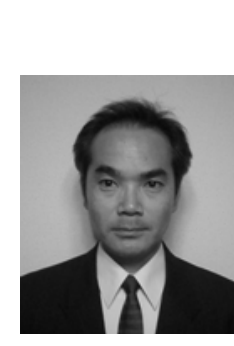

敦 (非会員) 1986 年電気通信大学電子工学科卒 業。同年山武八ネウエル(株) (現 , 株式会社山 武) 入社。主として通信 , ファジィプロセッサ， 画像処理などのディジタル LSI の研究開発に 従事。現在, 同研究開発本部主任研究員。

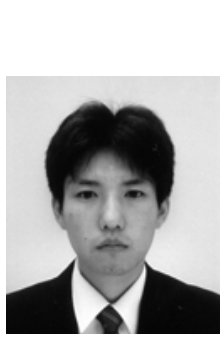

(非会員) 2000 年東北大学工学部電子工学科 卒業。2005 年同大学院情報科学研究科博士課 程修了。同年同大学情報科学研究科助手。 2004-2005 年日本学術振興会特別研究員。現在 に至る。画像処理 , バイオメトリクスに関する 研究に従事。IEEE, 電子情報通信学会, 情報 処理学会各会員。

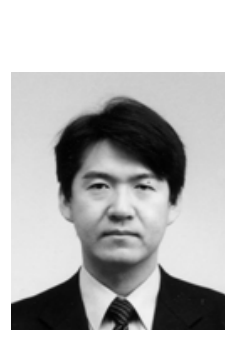

(非会員) 1988 東北大学工学部電子工学科卒 業。1992 同大学大学院工学研究科博士課程修 了。工学博士。同年同大学工学部電子工学科助 手, 1994 年同大学院情報科学研究科助手, 1996 年同助教授 , 2002 年同教授。1997-1999 年科 学技術振興事業団さきがけ研究 21 研究者兼任, 現在に至る。超高速ディジタル計算の理論，画 像センシング, 映像信号処理 , バイオメトリク ス, VLSI 設計技術, 多値論理, 分子コンピュータの基礎理論に関 する研究に従事。IEEE, 電子情報通信学会, 計測自動制御学会, 情報処理学会各会員。

樋口 龍 雄 (非会員) 1962 年東北大学工学部電子工学科

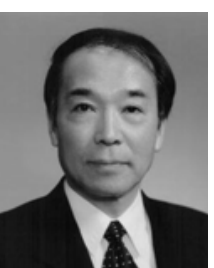
卒。1969 年同大学院工学研究科博士課程修了。 工学博士。1967 年同大学工学部電子工学科助 手, 1970 年同助教授, 1980 年同教授。1993 年同大学院情報科学研究科教授。1994-1998 年 同情報科学研究科長併任。1995-2001 年東北大 学情報処理センター長併任。2003 年東北工業 大学工学部電子工学科教授 ·東北大学名誉教 授 , 現在に至る。この間, ディジタル信号処理, 特に 1 次元および 多次元ディジタルフィルタの統一的設計ならびに信号処理プロセ ッサのアーキテクチャ, および多值集積回路, 超多值オプト・バイ オコンピューティングの研究に従事。IEEE, 電子情報通信学会, 計測自動制御学会各フェロー。 